構成要素の外形は，ラミネートで修復した上㖽中切歯 を唇舌方向に 2 分割した断面を拡大トレースすることに よって作成した，荷重の負荷位置は，切端接着部からわ ずかに唇側より（L 1 ），切端接着部からわずかに舌側 より（L 2 ），L 2 からわずかに歯䅡部より（L 3 ）およ び舌側の歯䅡部（L 4) に設定し, 荷重は $1 \mathrm{~kg}$ とした。 解析には平面ひずみを想定し, セメント厚さは 25 と $100 \mu \mathrm{m}$, レジン弾性率は 600 と $2000 \mathrm{~kg} / \mathrm{mm}^{2}$ をれぞれ 想定して, レジン層厚み掞よびレジン弾性率の影響を調 べた.

ポーセレン内に発生する最大主応力は， L 1 の場合を 除いて, 全体的に引張の主応力が発生し, 唇側歯頚部表 面には表面に沿った引張応力の応力集中がみられた。 ポーセレン内の応力は, L 4 の場合に他の場合と比べて 約 2 倍高い值となり, レジンの厚さやレジン弾性率には ほとんど影響されなかった。レジン接着層内に発生する 主応力はほとんよ゙引張応力で接着面にほぼ垂直に発生し ていた．主応力の分布は負荷位置の影響を強く受け， L 2 および L 3 では接着首の切端近傍に，L 1 および L 4 は切端から歯䅡部に沿った接着層のほぼ中央に施力の集 中がみられた、レジン接着層内の主応力は $\mathrm{L} 2$ の場合が 他の負荷位置に比べ大きくなり，L 4 の場合が最む小さ くなった，また，レジンの弾性率が低く，厚さが薄くな ると, 主応力は大きくなる傾向にあった。

\section{7. ポーセレン・ラミネートベニアの支台歯形成}

第 2 報 形成方法

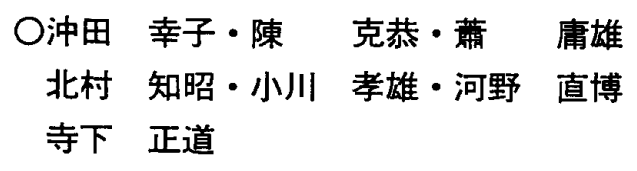

九歯大・保存 1

ポーセレン・ラミネートベニア修復は, 形成をエナメ 儿質内によどめるのが原則とされており，形成には十分 な配慮が必要である．今回は，3 通りの形成方法を用 い, 10 人の術者で，その削除量，形成面の状態，形成 の簡便さについて比較し，上り効果的な形成方法の検討 を行った。

ダイヤモンドポイント 1 本で歯軸方向のガイドグルー プ付与と面形成を行う IDA 法, ラウンドバーで㐘軸之 垂直方向にガイドグループを付与し，IDA 法より若干 細めのダイヤモンドポイントで面形成を行う KOD 法, $0.3 \mathrm{~mm}, 0.5 \mathrm{~mm}$ デプスカッターで歯軸之垂直方向にガイド グループを付与し，ダイヤモンドポイントで面形成を行
うLVS 法の 3 通りの方法で形成を行った.

形成時間は, ポイント 1 本で形成するIDA 法が他の 2 方法に比べ短い傾向にあった，削除量は歯頝部につい ては, KOD 法のみ指示した $0.3 \mathrm{~mm}$ の削除量をほぼ示し たが他の方法は削除量が多かった，切端部については IDA 法を除き, 中央部については 3 方法とも削除量の 不足が認められた。 3 方法とも数例においてがイドグ ループの取り残しが認められ，これが削除量の不足と なった原因の 1 つと思われる。 アンケート結果から，面 形成においては KOD 法が最む形成しやすく, 深さとガ イドグループについては LVS 法が最も形成しやすいと の結果が得られた。また IDA 法はダイヤモンドポイン トが若干大きく，また歯軸方向にガイドグループを付与 するため形成しにくいとの結果が得られた。

以上の結果よりガイドグループは歯軸方向より，歯軸 に垂直な方向の方が形成しやすく安全であることが考え られた. 削除量の面から歯頚部の形成には細いダイヤモ ンドポイントの方が良いと考えられ，歯冠中央部と切端 部は若干削除量が少なくなる傾向にあるためガイドグ ループの取り残しなどに注意する必要がある。

\section{62 例の形状記憶医用インプラントの臨床例につい} $\tau$

\section{○久保田孝文・久保田瑞恵・吉永 久秋 横本 満・荒牧 利裕・永野 裕治 藤井 智}

形状記憶医用学会北九州支部

日常の柬科口腔領域の臨床において, 多数㐘欠損や動 摇歯を有する症例．有床義㐘を好まない症例などに多々 遭遇する。

最近，われわれはこのような症例に施術の簡単な，そ して初期固定の堅固な形状記憶インプラント（SMI）を 62 例に応用し好結果を得た。

これらについて, 性差, 年令, インプラント対象欠損 部位, 使用インプラントの種類, SMI の植立後の容態 などを検索し，併せて診査，設計についても考察した。

男性 30 例，女性 32 例で女性が多く，また年令群では 20 才代 3 例，70才代も 3 例で，50-59才が最む多く 21 例であった。

インプラント対象欠損部位では，上顎は 67 が 4 例で 多く，下靧では 67 が 19 例， 567 が 17 例であった。使 用した SMI は 18-L が 19 例で最も多く, 続いて $24-\mathrm{L}$ が11例みられた。 